\title{
Mobbing og trakassering på jobb bør bli den nye \#metoo
}

\#metoo-kampanjen satte seksuell trakassering på dagsordenen. Nå må vi rette søkelyset mot mobbing på arbeidsplassen.

\section{Forfatter}

\section{Ingeborg Nilsen}

Helsesøster

Olsvik helsestasjon, Bergen kommune

\section{Nøkkelord}

\section{\begin{tabular}{ll|lll} 
Arbeidsmiljø & Fortelling Kunnskap mobbing Trakassering
\end{tabular}}

Sykepleien 2018 106(72645)(e-72645)

DOI: https://doi.org/10.4220/Sykepleiens.2018.72645

\section{HOVEDBUDSKAP}

Artikkelen formidler kunnskap om mobbing og trakassering og viser behovet for ny og erfaringsbasert kunnskap om temaet. Til slutt retter den oppmerksomheten mot verdien av kunnskap for å forebygge og håndtere trakassering i et arbeidsmiljø.

\#metoo-kampanjen (se faktaboks) har ført oss inn i en brytningstid når det gjelder kunnskap og erkjennelse om seksuell trakassering og varsling. Kan tiden nå også være moden for mer kunnskap og erkjennelse om mobbing på jobb? 
Mobbing er et viktig tema i den norske

samfunnsdebatten. Begrepene mobbing og trakassering

er uttrykk for krenkende og utilbørlig behandling av

mennesker i et arbeidsforhold.

Det foreligger betydelige mengder forskning om temaet, men behovet for å heve kunnskapsnivået er særlig stort hos arbeidsgivere og ledere. Samtidig er kunnskap om mobbing noe som alle i virksomheten må ha for å kunne ivareta kravene norsk regelverk stiller til alle i en virksomhet.

Hensikten med denne artikkelen er å formidle kunnskap om mobbing og trakassering, hevde behovet for ny og erfaringsbasert kunnskap om temaet og sette søkelyset på verdien av kunnskap for å forebygge og håndtere trakassering i et arbeidsmiljø.

\section{\#METOO}

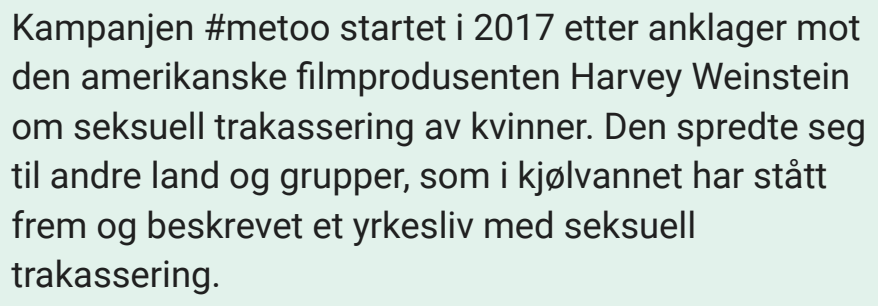

Kilde: NRK

\section{Førte til handling}

Gjennom \#metoo-kampanjen har kvinner fra mange land og fra ulike samfunnslag hevet stemmene og fortalt sine historier om seksuell trakassering. Endelig var tiden moden for å ta disse kvinnene og deres historier på alvor.

Sterke og modige kvinner som startet aksjonen, har vært til hjelp og støtte for kvinner som tidligere ikke har maktet å stå frem, eller som ikke har blitt hørt eller tatt på alvor når de har fortalt historiene sine. Modige kvinner utgjorde en forskjell og aktiverte aktører som kunne stoppe trakasseringen. 
Kampanjen presset frem handling. Overgriperne har måttet gå i seg selv og innse at de har handlet på en uakseptabel måte. De har måttet beklage trakassering og overgrep de har gjort seg skyldige i, og handlingene deres har fått konsekvenser for statusen deres og den videre karrieren. Kanskje tiden og samfunnskreftene nå er modne for kunnskap og erkjennelse om flere former for trakassering på arbeidsplassen?

LES: Sykepleieres historier om seksuell trakassering

\section{Trenger kunnskap}

Einarsen og medarbeidere (1) hevder at det foreligger et stort behov for økt kunnskap og kompetanse om mobbing og norsk lovverk på området. Behovet er særlig stort hos arbeidsgivere og ledere slik at de kan forebygge og håndtere mobbing på arbeidsplassen.

Forskning har vist at 4-5 prosent av norske arbeidstakere opplever alvorlig mobbing på jobb (2). Ordet mobbing brukes mest i dagligtale, mens ordet trakassering brukes når fenomenet skal beskrives rettslig. Mobbebegrepet og kunnskap om mobbing er likevel nyttig for å vise de store konsekvensene systematisk eksponering for både direkte og mer subtile, negative handlinger kan ha.

\section{三 «Forskning har vist at 4-5 prosent av norske arbeidstakere opplever alvorlig mobbing på jobb.»}

Arbeidsmiljøloven regulerer forbudet mot mobbing, men også et forbud mot å tie dersom man er vitne til, eller får kjennskap til, mobbing. Mobbing er derfor noe alle i virksomheten må ha kunnskap om.

\section{Trakassering vs. mobbing}


Arbeidsmiljøloven bruker begrepet trakassering istedenfor begrepet mobbing. Begge begrepene rommer et felles meningsinnhold for en type negativ atferd fra en leder eller medarbeider som truer arbeidstakerens trivsel, verdighet og selvrespekt (2).

Arbeidsmiljøloven skal beskytte arbeidstakere mot mobbing. I tillegg skal loven beskytte arbeidstakere mot «utilbørlig opptreden», «krenkelse av integritet og verdighet» og «uheldig psykisk belastning», som alle er mildere begreper enn begrepet mobbing. Arbeidsmiljøloven gir dermed ansatte i prinsippet sterkere beskyttelse mot krenkende handlinger enn det som strengt tatt kan defineres som mobbing (3).

Mobbing på arbeidsplassen betyr å bli systematisk utsatt for negative handlinger samtidig som man føler seg ute av stand til å beskytte seg mot disse handlingene (4).

\section{Krav til arbeidsmiljø}

Arbeidsmiljølovens formål er å sikre et arbeidsmiljø som gir grunnlag for en helsefremmende og meningsfylt arbeidssituasjon som gir full trygghet mot fysiske og psykiske skadevirkninger. Arbeidsgiveren skal sørge for at bestemmelsene i arbeidsmiljøloven blir overholdt. Arbeidsgiveren er følgelig pliktig til å tilrettelegge ansattes arbeidssituasjoner og deres samhandling med andre i samsvar med bestemmelsenes krav.

Som nevnt omfatter loven et forbud mot å tie dersom man er vitne til, eller får kjennskap til, trakassering. Enhver lege som gjennom sitt arbeid får kunnskap om at en arbeidstaker lider av sykdom som legen antar skyldes arbeidstakerens arbeidssituasjon, har skriftlig meldeplikt til Arbeidstilsynet (5). 
Kravene regelverket stiller til arbeidsmiljøet, er ment å ivareta arbeidstakernes interesser og beskytte arbeidstakerne mot uheldige belastninger som følger av arbeidet, arbeidets organisering eller det sosiale samspillet på arbeidsplassen.

Reglene som omhandler psykososialt og organisatorisk arbeidsmiljø, kan deles inn i et forebyggende og et gjenopprettende perspektiv. Det forebyggende perspektivet anviser hvilke jobbkomponenter som skal være til stede for at en jobbsituasjon skal være fullt forsvarlig og i tråd med arbeidsmiljølovens krav.

Reglene som faller inn under det gjenopprettende perspektivet, omhandler hva arbeidstakere ikke må finne seg i. De bygger primært på erkjennelsen av at brudd på regelverket medfører belastninger med stor sannsynlighet for helseskade. Arbeidsgiveren må straks iverksette tiltak for å rette opp forhold som bryter med arbeidsmiljølovens bestemmelser (6).

LES: Sykepleierhelse: - Må være bevisst på risikofakt orene

\section{Alle kan rammes}

Mobbing rammer både menn og kvinner, unge og eldre, ledere og medarbeidere. Det viser seg at de mest langvarige og alvorlige sakene har en tendens til å komme fra virksomheter innenfor helse, skole eller administrasjon. Å oppleve mobbing er forbundet med reduksjon i jobbtilfredshet, fysiske og mentale helseproblemer, skamfølelse, dårlig selvaktelse og manglende selvtillit.

\section{三 «Mobbing rammer både menn og kvinner, unge og eldre, ledere og medarbeidere.»}


Det er betydelige samfunnskostnader forbundet med sykefravær, medisinsk og psykologisk behandling samt arbeidsløshet og førtidspensjonering som følge av mobbing. Mobbing er også et problem for dem som observerer mobbingen, og viser seg hos observatørene i form av redusert jobbtrivsel og stressrelaterte plager (3).

Forskning indikerer at høyintensiv mobbing er belastende og skadelig for alle, og at helseplager opptrer uavhengig av om den som er utsatt for mobbing, selv mener at han eller hun kan forsvare seg mot mobbehandlingene. I de mest alvorlige mobbesakene handler det helt klart mer om hvordan man «har det», enn om hvordan man «tar det» (7).

Mobbing, også etter varsling, kan føre til både psykiske og fysiske helseproblemer og problemer knyttet til sosial fungering og yrkesdeltakelse. Noen av de vanligste tilstandene og symptomer hos personer som har vært utsatt for mobbing, er depresjon, søvnvansker, muskel- og skjelettplager, angstlidelser og symptomer som likner på PTSD (posttraumatisk stresslidelse). Dette kan igjen føre til problemer med familie, venner og kollegaer, yrkesdeltakelse og økonomi (4).

\section{Lederstil påvirker}

I en undersøkelse blant norske sykepleiere finner Pallesen og medarbeidere (8) sammenheng mellom mobbing på arbeid og mentale helseplager som depresjon, angst og utmattelse. Samtidig viser studien at symptomer på depresjon, angst og utmattelse økte eksponeringen for mobbing på arbeidsplassen.

Resultatene kan således indikere en ond sirkel der mobbing på arbeidsplassen og psykiske helseproblemer påvirker hverandre negativt. 
Studier viser sammenheng mellom mobbing og et arbeidsmiljø med dårlige eller fraværende ledere (3). I et dårlig psykososialt miljø vil det være større sannsynlighet for at mobbing oppstår enn i et arbeidsmiljø som er preget av god ledelse, ryddige organisatoriske forhold, åpenhet og tillit (2).

Laissez faire-lederskap, som innebærer la-det-skurelederegenskaper og ikke-responderende lederegenskaper, står frem som en tilretteleggings- og vedlikeholdsmekanisme i mobbeprosessen der offeret kan bli utsatt for fortsatt trakassering over lange perioder.

Derfor er det viktig med en aktiv, hensynsfull og problemløsende lederstil når mellommenneskelige forhold på arbeidsplassen blir giftige, og eskalerende konflikter, trakassering og mobbing utvikler seg (9).

\section{Underrapporteres}

Sakene om seksuell trakassering viser hvor belastende og krevende det kan være å varsle om kritikkverdige forhold på arbeidsplassen. Mange opplever at de ikke blir tatt på alvor, eller at forholdet de varsler om, ikke blir fulgt opp. Noen må varsle flere ganger før ledelsen tar tak i forholdet. Samtidig er det mange som lar være å varsle om trakassering.

\section{三 «Mange opplever at de ikke blir tatt på alvor, eller at forholdet de varsler om, ikke blir fulgt opp.»}

Årsaker til manglende varsling kan være frykt for represalier, liten tro på at det blir satt i verk tiltak mot trakasseringen og/eller at de ikke synes det er noe å varsle om (10-11). Einarsen og medarbeidere (3) viser til en landsrepresentativ undersøkelse fra 2005, der 4,5 prosent av arbeidsstokken oppga at de følte seg mobbet på jobb. 
Studien konkluderte imidlertid med at det finnes en klar underrapportering av mobbing fordi mange flere arbeidstakere rapporterte om en systematisk eksponering for en rekke spesifikke mobbehandlinger kombinert med meget lav jobbtilfredshet. Samme studie viste at rundt 13 prosent mente de hadde observert mobbing på sin egen arbeidsplass.

\section{Personlige fortellinger}

Fortellingene fra \#metoo-kampanjen har vært en viktig vekker. Kampanjen har belyst hvor nødvendig varsling er som en kontrollmekanisme i et velfungerende samfunn. Fortellingen som fremstillingsform er god til å formidle hverdagssituasjonene.

Gjennom fortellinger får hverdagsordene en naturlig plass i en faglig sammenheng. Noen hverdagsord er ladet med et stort faglig og kunnskapsmessig potensial, men i den vitenskapelige verdenen har disse ordene lav verdi som bærere av betydning, mening, faglig innhold og kunnskap (12).

Med bakgrunn i en dybdeundersøkelse av tretten personer som har blitt herset med på jobb, redegjør Underlid for hvordan de har opplevd og taklet den utilbørlige sosiale dominansen. Gjennom fortellingene til de dominerte får leseren innblikk i ulike former for negativ dominans $\mathrm{i}$ arbeidslivet som ligger $\mathrm{i}$ skjæringspunktet mellom mobbing og andre former for dårlig folkeskikk.

\section{三 «Vi trenger historiene om trakassering fortalt med subjektive og personlige begreper.»}


Fortellingene deres ligger til grunn for valget av teoretisk perspektiv på fenomenet og kaster lys over teoriene og forslagene til løsning. Ingen av de dominerte maktet å sette en effektiv stopper for den utilbørlige sosiale dominansen. Underlid oppfatter at de dominerte mangler språk for det de ble utsatt for fordi det var ukjente opplevelser de ikke hadde erfaring med fra tidligere. Derfor var de begrepsløse (13).

Følgelig har det stor betydning at de som har blitt trakassert, forteller om opplevelsene sine for å utvide og fornye begrepene, språket og kunnskapen vår om trakassering på jobb. Vi trenger historiene om trakassering fortalt med subjektive og personlige begreper.

\section{Kunnskapens vesen}

I folkeeventyret «Risen som ikke hadde noe hjerte på seg» $(12,14)$ drar Askeladden ut på leting etter sine seks eldre brødre. De hadde reist ut for å fri, men kom ikke tilbake fordi risen hadde omskapt brødrene og kjærestene deres til steiner.

Risen har en veldig og ukontrollert makt i situasjonen. Han er sterk, uberegnelig og vanskelig å beseire fordi han har hjertet sitt et sted som bare han selv kjenner til. Risen har gjemt hjertet sitt og dermed kamuflert sin sårbarhet. En viktig oppgave for Askeladden blir å finne risens hjerte slik at han kan påvirke risen og risens maktutøvelse.

Lundstøl (12) hevder at kunnskapens vesen er skjult som risens hjerte. Han ser på risen som en metafor for sterke samfunnskrefter som påvirker oss, men som er vanskelige å identifisere og fastholde i den sosiale virkeligheten vi står i og er en del av. Samfunnet vårt er karakterisert ved at vi søker å innpasse kunnskap i sosiale samfunnsmessige systemer hvor kunnskapen får en stor effekt og inngår i virkningsfulle strategier. 
Kunnskapens vesen er på sett og vis i hjertet.

«Kunnskapen eller trekkene ved den sosiale tilværelse, hvor enkeltmennesker, møtet mellom mennesker og alt som er knyttet til selvet, identiteten og den nære kontakt, har en mer skjult, indirekte eller uklar plassering i forhold til systemkreftene.» (12, s. 57) Er det slik at kunnskapens vesen - den erfaringsbaserte kunnskapen - også er skjult når det gjelder trakassering og mobbing?

Det foreligger store mengder forskning om trakassering og mobbing på jobb (3-4, 7-9, 13). Samtidig påpeker Underlid at ingen av de dominerte i studien hans maktet å sette en effektiv stopper for den utilbørlige sosiale dominansen de opplevde. De manglet begreper og språk for opplevelsene sine. Derfor blir det nødvendig å utvide og fornye kunnskapen og få nye begreper og en ny bevissthet om trakassering i arbeidslivet.

Fortellingene til de trakasserte kan få en mer direkte og klar plassering og påvirkning overfor systemkreftene når kunnskapen om trakassering på jobb blir mer nyansert med kunnskapen de trakasserte har i hjertene sine. Kan institusjoner og modige personer sette i gang en slik kampanje og aktivere samfunnsaktører som kan ivareta bestemmelsene i arbeidsmiljøloven?

\section{Veien videre}

Askeladden brukte kløkt og gode hjelpere for å finne risens hjerte og få frigjort brødrene sine og kjærestene deres. \#metoo-kampanjen viste at det finnes gode hjelpere og aktører med makt som kan handle mot urett. De seksuelt trakasserte hevet stemmene sine, fortalte om trakassering og overgrep. Denne kunnskapen førte til en ny bevissthet i samfunnet og aktiverte myndige krefter, slik at overgripernes hjerter ble rammet, og deres misbruk av makt stoppet. 
Arbeidstakere, arbeidsgivere og ledere må heve kunnskapen de har om trakassering og mobbing. Samtidig ser det ut til å være behov for ord, språk og fortellinger som kan formidle de personlige erfaringene med mobbing og trakassering $\mathrm{i}$ arbeidslivet. Dersom modige arbeidstakere sier ifra, tar ansvar og tåler belastninger på vegne av dem som ikke makter, er gjerne tiden moden og samfunnskreftene klare for å renske ut trakassering og mobbing på arbeidsplassen.

Kan modige kvinner og menn utgjøre en forskjell i kampen mot trakassering ved å heve stemmene sine, fortelle sine historier og bidra til å aktivere myndige samfunnsaktører til å ivareta formålet med arbeidsmiljøloven?

Jeg har tro på at tiden nå er moden for å få frem fortellingene til dem som har blitt trakassert på jobb. Gjennom fortellingene kan kunnskapen fornyes, deres overgripere stoppes og verdigheten, helsen og deltakelsen i arbeidslivet gjenopprettes.

Som et viktig bidrag i denne retningen vil jeg utfordre Sykepleien til å sende ut tilsvarende undersøkelse om trakassering og mobbing på jobb som de gjorde for seksuell trakassering. Utfordringen går også til modige lesere av Sykepleien. Vi trenger de egenopplevde historiene om trakassering fortalt med subjektive og personlige ord for å fornye kunnskapen og aktivere myndige samfunnsaktører mot trakassering i arbeidslivet.

\section{Referanser}

1. $\quad$ Einarsen S, Glasø L, Vie TL, Pedersen H. Mobbing i arbeidslivet. En veileder for arbeidsgivere, tillitsvalgte og ledere. Bergen: Idébanken; 2009.

Tilgjengelig fra: http://mag.idebanken.org/mobbing/3/ (nedlastet 13.03.2018). 
2. Einarsen S, Pedersen H. Håndtering av

konflikter og trakassering i arbeidslivet. Oslo:

Gyldendal Norsk Forlag; 2014.

3. Einarsen S, Glasø L, Nielsen MB. Mobbing i arbeidslivet: En litteraturoversikt. Tidsskrift for Norsk psykologforening. 2008;(45)3:308-17. Tilgjengelig fra: http://www.psykologtidsskriftet.no/index.php?seks id $=41589 \& a=2$ (nedlastet 16.03.2018).

4. Bjørkelo B, Magerøy N, Magerøy K. Veien videre: Psykoterapi for arbeidstakere med mobbeerfaringer. Tidsskrift for Norsk psykologforening. 2011;48(8):758-65. Tilgjengelig fra: http://www.psykologtidsskriftet.no/index.php?seks $\mathrm{id}=149162 \& \mathrm{a}=3$ (nedlastet 14.03.2018).

5. Lov 17. juli 2005 nr. 62 om arbeidsmiljø, arbeidstid og stillingsvern mv. (arbeidsmiljøloven). Tilgjengelig fra: https://lovdata.no/dokument/NL/lov/2 005-06-17-62 (nedlastet 25.03.2018).

6. Pedersen H, Einarsen S. Arbeidsmiljøloven som rettesnor for det psykososiale og organisatoriske arbeidsmiljøet. I: Einarsen S, Skogstad A, red. Det gode arbeidsmiljø. Krav og utfordringer. 2. utg. Bergen: Fagbokforlaget; 2014. s. 392-419.

7. Nielsen MB, Gjerstad J, Jacobsen DP, Einarsen SV. Does ability to defend moderate the association between exposure to bullying and symptoms of anxiety? Front. Psychol. 2017(1953):111. Tilgjengelig fra: https://doi.org/10.3389/fpsyg.201 7.01953 (nedlastet 04.04.2018).

8. Pallesen S, Magerøy N, Moen BE, Bjorvatn B, Einarsen S. Exposure to bullying behaviors as a predictor of mental health problems among Norwegian nurses: Results from the prospective SUSSH-survey. International Journal of Nursing Studies. 2014;51(3):479-87. Tilgjengelig fra: https://doi.org/10. 1016/j.jjnurstu.2013.06.017 (nedlastet 04.04.2018). 
9. Glambek M, Skogstad A, Einarsen S.

Workplace bullying, the development of job insecurity and the role of laissez-faire leadership: A two-wave moderated mediation study. Work \& Stress. 2018. Tilgjengelig fra: https://doi.org/10.1080/02678373.201 8.1427815 (nedlastet 31.03.2018).

10. Vollheim T. Arbeidsgivere må ta varsling på alvor. Arbeidstilsynet; 2018. Tilgjengelig fra: https://w ww.arbeidstilsynet.no/nyheter/arbeidsgivere-ma-ta-var sling-pa-alvor/ (nedlastet 02.04.2018).

11. Sykepleien. Hva skjer. Seksuell trakassering. Sykepleien. 2018;106(2):14-21.

12. Lundstøl J. Kunnskapens hemmeligheter. Oslo: Cappelen Akademisk; 1999.

13. Underlid K. Å bli hersa med. Utilbørlig sosial dominans på arbeidsplassen. 1. utg. Oslo: Gyldendal Norsk Forlag; 2013.

14. Asbjørnsen PC, Moe J. Samlede eventyr. Første bind. Oslo: Gyldendal Norsk Forlag; 1975. 